\title{
Non-steroidal Anti-inflammatory Drugs and Endometrial Cancer Risk in the VITamins And Lifestyle (VITAL) Cohort
}

\author{
Theodore M. Brasky ${ }^{1,2}$, Kirsten B. Moysich ${ }^{3}$, David E. Cohn ${ }^{4}$, and Emily White ${ }^{2}$ \\ ${ }^{1}$ The Ohio State University College of Medicine, Department of Internal Medicine, Division of \\ Cancer Prevention \& Control, Columbus, $\mathrm{OH}$ \\ ${ }^{2}$ Fred Hutchinson Cancer Research Center, Cancer Prevention Program, Seattle, WA \\ ${ }^{3}$ Roswell Park Cancer Institute, Division of Cancer Prevention and Population Sciences, Buffalo, \\ NY \\ ${ }^{4}$ The Ohio State University College of Medicine, Department of Obstetrics and Gynecology, \\ Division of Gynecologic Oncology, Columbus, $\mathrm{OH}$
}

\begin{abstract}
Background-Chronic inflammation may be an important factor in the initiation and promotion of endometrial cancer. Use of non-steroidal anti-inflammatory drugs (NSAIDs), however, has been inconsistently associated with endometrial cancer risk.
\end{abstract}

Methods-22,268 female residents of western Washington State, ages 50-76, completed a baseline questionnaire in 2000-2002 and reported on their use of individual NSAIDs over the past 10 years. Use was categorized as none, low ( $<4$ days/week or $<4$ years), and high ( $\geq 4$ days/week and $\geq 4$ years). Over 9 years of follow-up, 262 incident invasive endometrial cancers were identified. Multivariable proportional hazards models were used to estimate hazard ratios (HR) and $95 \%$ confidence intervals $(\mathrm{CI})$.

Results-Relative to non-use, high use of aspirin was inversely associated with endometrial cancer risk (HR 0.64, 95\% CI: 0.41-1.01; $P$ trend=0.03). Findings were stronger for regularstrength than low-dose aspirin. High use of non-aspirin NSAIDs (HR 1.15, 95\% CI: 0.68-1.95), including ibuprofen (HR 1.29, 95\% CI: 0.73-2.28), and naproxen (HR 1.08, 95\% CI: 0.39-2.95) were not associated with risk. In subgroup analyses, findings for aspirin were strongest for cancers of endometrioid histology and were restricted to non-smokers.

Conclusions-This study provides additional evidence that use of aspirin, but not non-aspirin NSAIDs, may reduce the risk of endometrial cancer, especially in estrogen-mediated cases; however additional prospective studies with high-quality measurement of NSAID use are needed. Aspirin should continue to be examined as a potential agent for cancer chemoprevention.

(C) 2012 Elsevier Inc. All rights reserved.

Address for Correspondence: Theodore M. Brasky, The Ohio State University Comprehensive Cancer Center, Suite 525, Gateway Building C, 1590 N High St., Columbus, OH 43201, Phone: 614-293-3772, Fax: 614-366-5454, Theodore.Brasky@ osumc.edu.

Publisher's Disclaimer: This is a PDF file of an unedited manuscript that has been accepted for publication. As a service to our customers we are providing this early version of the manuscript. The manuscript will undergo copyediting, typesetting, and review of the resulting proof before it is published in its final citable form. Please note that during the production process errors may be discovered which could affect the content, and all legal disclaimers that apply to the journal pertain.

Conflict of Interest Statement

The authors declare that there are no conflicts of interest. 


\section{Keywords}

Aspirin; Ibuprofen; Naproxen; NSAID; Endometrial Cancer

\section{Introduction}

Inflammation plays an important role in the development and progression of cancers at several anatomic sites [1], including the endometrium [2]. Recent findings from large prospective studies have shown that increases in blood markers of inflammation may be associated with increases in endometrial cancer risk [3-5]. It is estimated that cyxlooxygenase (COX)-2, which is responsible for the conversion of arachidonic acid $(\omega-6)$ to pro-inflammatory prostaglandins, is expressed in 35-92\% of endometrial cancers [6-8]. There is also limited evidence that inhibition of COX-2 through the use of non-steroidal anti-inflammatory drugs (NSAIDs) may reduce estrogen synthesis $[9,10]$, a major driver of endometrial proliferation $[11,12]$.

The use of NSAIDs has been associated with reductions in endometrial cancer in some [1316] but not all [17-22] epidemiologic studies. Findings from randomized trials have also been inconsistent [23, 24]. Recently, Rothwell et al. [24], reported a protective effect for uterine cancer $(P=0.003)$ in a pooled analysis of 51 randomized trials of aspirin and cancer risk. Inferences from existing studies remain limited because randomized trials only examined aspirin use, some at low doses; most cohort studies only examined current, shortterm use $[15,19,20]$; and no study to date has addressed individual types of commonly available non-aspirin formulations, which may have differing effects [25].

Here we give findings from our investigation of the association between long-term use of individual NSAIDs and endometrial cancer risk in a large, prospective study of women living western Washington State.

\section{Methods}

\section{Study population}

Participants were female members of the VITAL cohort, a prospective study designed to investigate the associations of dietary supplements and other behaviors, including over-thecounter medication use, with cancer risk. Detailed methods are given in White et al. [26]. Briefly, men and women, ages 50-76 years at baseline, who lived in the 13-county region of western Washington State covered by the Surveillance, Epidemiology, and End Results (SEER) cancer registry were eligible to participate. Because this paper is limited to women, we describe here recruitment of women. Using names purchased from a commercial list, we mailed baseline questionnaires and post-card reminders two weeks later to 168,953 women between October 2000 and December 2002. Among these, 40,337 were returned and deemed eligible. We excluded participants with a positive or missing history of uterine $(\mathrm{n}=877)$, ovarian $(\mathrm{n}=25)$, or breast cancer $(\mathrm{n}=1,833)$ at baseline, participants who had a hysterectomy or were missing this datum $(\mathrm{n}=15,079)$, as well as incident diagnoses of in situ endometrial cancer $(n=2)$ or endometrial cancers of mesenchymal origin or mixed tumor types $(\mathrm{n}=14)$. We additionally excluded 239 participants who were missing baseline NSAID data. After exclusions there were 22,268 women available for study. All participants gave informed consent and study procedures were approved by the Institutional Review Board at the Fred Hutchinson Cancer Research Center. 


\section{Data collection}

The baseline questionnaire included a detailed assessment of participants regular use of NSAIDs, defined as $\geq 1$ day/week for $\geq 1$ year, including frequency (days/week) and duration of use (years) in the past 10 years of low-dose aspirin, regular or extra-strength aspirin, ibuprofen, naproxen, and COX-2 inhibitors, celecoxib or rofecoxib. Use of each drug over the 10 years prior to baseline was categorized as none; low, $<4$ days/week or $<4$ years; and high, $\geq 4$ days/week and $\geq 4$ years. Additional variables included: 'total aspirin', defined as the maximum of 10-year use of low-dose or regular/extra-strength aspirin; 'non-aspirin NSAIDs', defined as the maximum of 10-year use of ibuprofen, naproxen, or celecoxib/ rofecoxib; and 'any NSAIDs', defined as the maximum of 10-year use of any of the NSAIDs assessed. Each variable was categorized as none, low, and high use as for individual NSAIDs. Use of the analgesic acetaminophen was not analyzed as it has little anti-inflammatory capacity [27].

In addition to data on NSAID use, we collected information at baseline on endometrial cancer risk factors and indications/contraindications of NSAID use. Participants reported their demographic and health-related characteristics, including height and weight [from which body mass index (BMI, $\mathrm{kg} / \mathrm{m}^{2}$ ) was computed], education, family history of cancer, and medical history including detailed information on reproductive health. Participants who reported having had a heart attack, angina, angioplasty, or bypass surgery were considered to have a positive history of coronary artery disease. Participants also answered several questions regarding cigarette smoking behavior including the age at which they started smoking daily, whether they currently smoked as baseline, the number of cigarettes smoked each day, and the cumulative years of smoking. From these data, we computed pack-years of smoking and number of years since quitting.

\section{Case ascertainment}

Participants were followed for incident endometrial cancer diagnoses from baseline to December 31, 2010, with a median follow-up time of 9 years. Incident, primary, invasive endometrial cancers (ICD-O C54.1) were ascertained by linking the study cohort to the western Washington SEER cancer registry, which is maintained by the Fred Hutchinson Cancer Research Center. All incident cancer cases, except non-melanoma skin cancer, diagnosed within the 13-country region are reported to SEER along with stage, histologic subtype, and other tumor characteristics [28]. Cases were ascertained through all area hospitals, offices of pathologists, oncologists, and radiotherapists, and from state death certificates. Extensive quality-control procedures ensure that registry data are accurate and complete. Linkage to SEER is based on ranking of the agreement between characteristics common to VITAL and SEER including name, social security number, date of birth, etc.; matches with high concordance were made automatically, while visual inspection was performed for matches in which some, but not all criteria matched. 262 incident, primary, invasive endometrial cancer cases were diagnosed among eligible women between baseline and December 2010.

\section{Follow-up for censoring}

Excluding the 262 incident cases of endometrial cancer, participants were right-censored from the analysis at the earliest date of the following events: withdrawal from the study $(n=9)$, death $(n=1,394)$, emigration out of the SEER catchment region $(n=1,469)$, or December 31, 2010, the most recent date of linkage to the SEER registry $(n=19,134)$. Deaths that occurred in the cohort were ascertained by linkage to the Washington State death file, using procedures similar to the SEER linkage. The National Change of Address System and active follow-up by telephone calls and mailings were used to identify participants who moved out of the study region. 


\section{Statistical analyses}

Age-adjusted Cox proportional hazards regression models were used to estimate hazard ratios (HR) and 95\% confidence intervals (CI) for associations between participant characteristics and endometrial cancer risk. Multivariable-adjusted Cox proportional hazards models were used to estimate HR and 95\% CI for associations between use of NSAIDs and endometrial cancer risk. Participants' ages were used as the time metric in regression models, with left-truncation at age at baseline. All reported $P$ values are two-sided and $P$ values for trend ( $P$ trend) were calculated by coding categorical NSAID variables as a single trend variable taking on values 0,1 , and 2 in Cox regression models. SAS v9.2 (Cary, NC) was used for all statistical analyses.

We selected potential confounders, a priori, for adjustment in multivariable models, including known or suspected risk factors for endometrial cancer. Our model included age (time variable); race (white/black/other); education ( Shigh school, some college, college graduate or advanced degree); body mass index (<25.0, 25.0-29.9,30.0-34.9, $\left.235.0 \mathrm{~kg} / \mathrm{m}^{2}\right)$; pack-years of smoking (non-smokers and tertiles of smokers); alcohol consumption (drinks/ day: non-drinkers, $<1.0,1.0-1.9, \geq 2.0$ ); physical activity (MET-hours/week: inactive and tertiles of activity); age at menarche ( $\leq 1,12,13, \geq 14)$; age at menopause ( $\leq 44,45-49, \geq 50$, premenopausal, perimenopausal); parity (nulliparous, 1-2, 3-4, >5); combined hormone therapy (never/former/current); estrogen-only hormone therapy (never/former/current); years of oral contraceptive use $(0,0.1-4,5-9, \geq 10)$; oophoerectomy (yes/no); family history of uterine cancer (yes/no); family history of ovarian cancer (yes/no); and history of diabetes (yes/no). To address the issue of confounding by indication, we further adjusted regression models for indications/contraindications of NSAID use, including (yes/no for each of the following): history of coronary artery disease; history of stroke; history of osteoarthritis/ chronic joint pain; history of rheumatoid arthritis; history of migraine/chronic headaches; and history of ulcers. Regression analyses for any one NSAID exposure were further adjusted for use of other NSAIDs.

We hypothesized a priori that the association between NSAID use and endometrial cancer may be modified by smoking, BMI, and use of combined hormone therapy, factors which are associated with inflammation [29-31]. Therefore, we performed stratified analyses by smoking status (never vs. ever), BMI ( $<30$ vs. 230 ), and use of combined hormone therapy (never/former vs. current). $P$ values for multiplicative interaction ( $P$ interaction) were calculated by including a cross-product term between dichotomous variables for NSAID exposure (use/non-use) and the effect modifier in the unstratified multivariable models.

We additionally performed a subgroup analysis examining the association between NSAID use and endometrial cancer risk, restricting incident cancers to those of endometrioid subtypes ( $\mathrm{n}=227$ ), which are thought to be estrogen responsive [32]. We hypothesized that NSAIDs would more strongly reduce the risk of this histology. Diagnoses of clear cell and serous cell subtypes were right-censored at their respective dates of diagnosis.

\section{Results}

In this cohort, female NSAID users tended to be older, smoke more, and consume alcohol and red meat in greater amounts [33]. NSAID users were also more likely to have a history of coronary heart disease, diabetes, hypertension, and arthritis [33]. Age-adjusted associations between participant characteristics and endometrial cancer risk are given in Table 1. Findings were generally consistent with the literature: increasing age, body size, age at menopause, and positive family histories of uterine or ovarian cancers were associated with increased risks of endometrial cancer; whereas smoking, increasing alcohol consumption, physical activity, age at menarche, parity, and increasing duration of 
combined hormone therapy or oral contraceptive use were associated with reduced risks of endometrial cancer. Reflective of the change in clinical practice after unopposed estrogens were found to increase endometrial cancer risk, few women in VITAL were taking unopposed estrogens at baseline. Inconsistent with the literature, a history of diabetes and current use of unopposed estrogens at baseline were not associated with increased risks of endometrial cancer (however, increased duration of estrogen therapy was suggestive of a positive association).

Table 2 gives associations between NSAID use and endometrial cancer risk. Relative to non-use, high 10-year use of aspirin was associated with a linear reduction in endometrial cancer risk (HR 0.64, 95\% CI: $0.41-1.01 ; P$ trend=0.03). Relative to non-use, any use of aspirin $\geq 1$ day/week and $\geq 1$ year was associated with a $28 \%$ reduction in endometrial cancer risk (HR 0.72, 95\% CI: 0.53-0.98; data not shown). The finding for 10-year use was driven by use of regular-strength (high vs. non-use: HR $0.53,95 \% \mathrm{CI}$ : $0.27-1.04 ; P$ trend=0.06) rather than low-dose aspirin (high vs. non-use: HR 1.00, 95\% CI: 0.62-1.62; $P$ trend=0.65), although neither finding reached statistical significance. Use of non-aspirin NSAIDs considered as a class or individually was not associated with endometrial cancer risk. In a sensitivity analysis examining the association between use of NSAIDs and endometrial cancers of endometrioid histologies $(\mathrm{n}=227)$, we found the association for high 10-year aspirin use to be strengthened (HR 0.60, 95\% CI: $0.37-0.97$; $P$ trend=0.01), driven by a stronger, linear inverse association between regular-strength aspirin use and endometrial cancer of endometrioid histology (HR 0.46, 95\% CI: $0.21-0.99 ; P$-trend=0.02) (data not shown). The associations between other NSAIDs were not appreciably changed when the analysis was restricted to endometrioid histologies.

Table 3 gives associations between total, low-dose, and regular-strength aspirin use and endometrial cancer risk, stratified on smoking status (never vs. ever), combined hormone replacement therapy (never/former vs. current), and BMI ( $<30$ vs. 230$)$. The inverse association we observed for aspirin and endometrial cancer appeared to be restricted to never smokers (HR 0.55, 95\% CI: 0.37-0.82) versus ever smokers (HR 1.25, 95\% CI: $0.77-$ 2.04; $P$ interaction=0.04), and possibly to current (HR $0.49,95 \%$ CI: $0.22-1.10)$ rather than never or former users of combined HRT at baseline (HR 0.98, 95\% CI: 0.66-1.45; $P$ interaction=0.10). For each comparison, the associations tended to be stronger for regularstrength rather than low-dose aspirin, although all comparisons by dose were statistically non-significant due to small numbers. There was no evident heterogeneity in the association between aspirin and endometrial cancer risk by participants' obesity status.

\section{Discussion}

In this large, prospective cohort study of women living in western Washington State, regular, long-term use of aspirin was associated with a reduction in endometrial cancer risk, particularly of endometrioid histology and among non-smokers. Use of ibuprofen and naproxen were not associated with risk.

There is increasing evidence that inflammation and the COX pathway are involved in endometrial carcinogenesis. In response to cytokines, growth factors, and oncogenes, the COX-2 enzyme converts arachidonic acid to prostaglandins, among which several are associated with angiogenesis and tumor growth in endometrial cancers [2]. In vitro experimental studies have shown increases in COX expression to result in increases of prostaglandin $\mathrm{E}_{2}$, aromatase, and estrogen synthesis $[9,34]$, which is important because unopposed estrogens are hypothesized to be the primary drivers behind endometrial proliferation $[11,12]$. In vitro findings are further supported by positive correlations between expressions of COX-2 and aromatase in human endometrial cancer tissue [8], and a

Gynecol Oncol. Author manuscript; available in PMC 2014 January 01. 
recent finding from the Nurses' Health Study that use of NSAIDs is associated with reduced blood concentration of estrogen among postmenopausal women [10]. COX-2 is also strongly expressed in early tumors of in vivo models of endometrial cancer, suggesting that it plays a role in cancer initiation and progression $[2,35]$. Although the NSAIDs under study are all known to bind to COX-2, we found that only the use of aspirin, and not ibuprofen or naproxen, was associated with reduced risks of endometrial cancer. One possible explanation for this difference in association is that unlike non-aspirin NSAIDs, aspirin binds irreversibly to COX-2 [36]. It is unclear, however, whether this would translate into greater anti-cancer properties. The stronger, linear reductions in risk observed between aspirin use and endometrial cancer of endometrioid histology, which are highly estrogensensitive [32], support, albeit indirectly, in vitro findings suggesting an association between inflammation and estrogen synthesis.

Among five case-control studies [13, 14, 16-18], four prospective cohort studies [15, 1921], a randomized controlled trial [23], and a pooled analysis of randomized controlled trials [24] which have examined the association between aspirin use and endometrial cancer risk, our findings are supported by two case-control studies, one cohort study, and the pooled analysis of trials. In a recent paper, Neill et al. [16], reported results from a population-based case-control study of Australian women and a meta-analysis of epidemiologic studies. In the case-control analysis, ever use of aspirin (OR 0.78, 95\% CI: 0.62-0.97) and increasing frequency of use ( $22 /$ week vs. never use: OR $0.54,95 \%$ CI: $0.38-0.78 ; P$ trend $<0.0001$ ) were associated with reductions in endometrial cancer risk. In their meta-analysis, aspirin was found to reduce endometrial cancer risk by $13 \%$ (RR 0.87, 95\% CI: 0.79-0.96) [16]. Similarly, Fortuny et al. [14], found that ever use of aspirin was associated with a $30 \%$ reduction (OR 0.7, 95\% CI: 0.4-1.0) in endometrial cancer risk in a population-based casecontrol study of women in New Jersey. In the NIH-AARP Diet and Health cohort, Danforth et al. [19], observed a strong reduction in endometrial cancer risk among very high users of aspirin ( 22 /day vs. non-use: RR $0.55,95 \%$ CI: $0.31-0.95$ ). The remaining observational studies observed no overall reduction in endometrial cancer risk [13, 15, 17, 18, 20, 21]. Authors of the Multiethnic Cohort study were recently the first to examine the association between NSAIDs and endometrial cancer histologies; they observed no association overall and no differences by histologic subtype [21]. In contrast, in the Australian case-control study (mentioned above), Neill et al. [16], reported similar reductions in risk regardless of endometrial cancer histology. Among randomized trials, no effect on uterine cancer was reported in the Women's Health Study trial of 100mg aspirin given every other day for an average of 10 years (RR 1.22, 95\% CI: 0.94-1.58). In contrast to the Women's Health Study and similar to our finding, Rothwell et al. [24], recently reported a protective effect of aspirin contrasted against a placebo on uterine cancer incidence $(P=0.003)$ in a pooled analysis of 51 randomized trials of aspirin and cancer incidence. However, in both cases the uterine cancer endpoints may have included some cervical cancers and cancers of mesenchymal origin.

Our finding of no associations between long-term use of non-aspirin NSAIDs, individually or in sum, are consistent with the literature. Although none have examined the use of these medications individually, authors of one case-control [14] and four prospective cohort studies [15, 19-21] have investigated the use of non-aspirin NSAIDs as a group with endometrial cancer. Similar to our findings, none reported an association. Lastly, a recent report from the Women's Health Initiative examining NSAID use as a group found no association with endometrial cancer [22]. In that study, only current use was assessed.

In subgroup analyses, we observed effect-modification by smoking status, and no statistically significant interaction by BMI or HRT use. To our knowledge, this is the first study to examine effect-modification by smoking. Because aspirin is metabolized by some 
of the same enzymes which are responsible for the metabolism of polycyclic aromatic hydrocarbons $(\mathrm{PAH})$ found in cigarette smoke, it is possible that our finding represents a biological phenomenon [37-39]. However, our finding that the inverse association between aspirin and endometrial cancer risk was restricted to never smokers is complicated by the well-established risk reduction for endometrial cancer among smokers. Thus, these findings clearly warrant replication in larger samples that will allow for a more detailed analysis of this initially detected interaction.

Whereas we observed an inverse association between aspirin and endometrial cancer risk overall, two studies $[13,15]$ and a meta-analysis [16] reported inverse associations between aspirin use and endometrial cancer risk restricted to obese women only. Moysich et al. [13], reported that use of aspirin $\geq 1$ day/week for $\geq 6$ months was associated with a $50 \%$ reduction in endometrial cancer risk (OR 0.50, 95\% CI: 0.27-0.92) among obese women (BMI>30) and no association among overweight (25 $₫ \mathrm{BMI} \leq 30$; OR $1.21,95 \% \mathrm{CI}$ : $0.65-2.23$ ) or normal-weight (18.5 $\mathrm{BMI}<25$; OR 1.61, 95\% CI: 0.71-1.90) women. In an analysis of the prospective Nurses' Health Study, including 82,971 women and 747 incident cases identified over $>24$ years of follow-up, Viswanathan et al. [15], reported that relative to nonuse, current use of aspirin was associated with a 44\% reduction (RR 0.66, 95\% CI: $0.36-$ 0.95 ) in endometrial cancer risk among obese (BMI 230$)$ women, and a statistically significant increase in risk among non-obese women (1.41, 95\% CI: 1.05-1.89; $P$ interaction=0.009). In their meta-analysis, Neill et al. [16], found that aspirin was inversely associated with endometrial cancer only among obese women (BMI $\geq 30$, RR $0.72,95 \%$ CI: $0.58-0.90$; BMI<30, RR 1.08, 95\% CI: 0.82-1.43). Similar to our findings, several others observed no differences by BMI [14, 17-21]. Authors of the Nurses' Health Study additionally reported a reduction in endometrial cancer among never users of postmenopausal hormones (RR 0.64, 95\% CI: 0.45-0.91) and increases in risk among ever users (RR 1.34, 95\% CI: 0.94-1.89; Pinteraction=0.046) [15]. No study, including this one, has replicated the latter finding.

The major strengths of the VITAL study include: 1) its prospective nature and nearcomplete follow-up of participants; 2) collection of long-term use of individual NSAIDs; and 3) our strong ability to statistically control for the potential confounding effects of indications/contraindications of NSAID use. The chief limitation of this study is that we did not collect data on the number of NSAID pills taken per day, or dose of individual nonaspirin NSAIDs. Such measurement error could potentially explain a null finding for nonaspirin NSAIDs, but findings for aspirin would be in spite of such error. An additional limitation is that we did not prospectively update participants' post-baseline NSAID exposures, further contributing to measurement error. Lastly, a relatively small percentage of women were high users of non-aspirin NSAIDs. It is therefore possible that analyses of the uses of these medications lacked statistical power.

In this large, prospective study of women living in western Washington State, we provide added evidence that long-term, regular use of aspirin is associated with reductions in endometrial cancer risk; particularly for endometrioid tumors and among non-smokers. Given the inconsistent nature of studies which have examined NSAIDs and endometrial cancer thus far, additional prospective studies with high-quality measurement of NSAID use are needed before a public health recommendation could be made. Nevertheless, given the evidence that aspirin reduces the risk of colorectal cancer $[40,41]$ and possibly other cancers $[24,42,43]$, our findings add support of aspirin for cancer chemoprevention.

Gynecol Oncol. Author manuscript; available in PMC 2014 January 01. 


\section{Acknowledgments}

This work is supported by National Institutes of Health grants R25-CA094880 (National Cancer Institute) and K05CA154337 (National Cancer Institute and Office of Dietary Supplements).

\section{References}

1. Coussens LM, Werb Z. Inflammation and cancer. Nature. 2002; 420:860-867. [PubMed: 12490959]

2. Wallace AE, Gibson DA, Saunders PT, Jabbour HN. Inflammatory events in endometrial adenocarcinoma. J Endocrinol. 2010; 206:141-157. [PubMed: 20406782]

3. Dossus L, Becker S, Rinaldi S, Lukanova A, Tjonneland A, Olsen A, Overvad K, Chabbert-Buffet N, Boutron-Ruault MC, Clavel-Chapelon F, Teucher B, Chang-Claude J, Pischon T, Boeing H, Trichopoulou A, Benetou V, Valanou E, Palli D, Sieri S, Tumino R, Sacerdote C, Galasso R, Redondo ML, Bonet Bonet C, Molina-Montes E, Altzibar JM, Chirlaque MD, Ardanaz E, Buenode-Mesquita HB, van Duijnhoven FJ, Peeters PH, Onland-Moret NC, Lundin E, Idahl A, Khaw KT, Wareham N, Allen N, Romieu I, Fedirko V, Hainaut P, Romaguera D, Norat T, Riboli E, Kaaks R. Tumor necrosis factor (TNF)-alpha, soluble TNF receptors and endometrial cancer risk: The EPIC study. Int J Cancer. 2010

4. Dossus L, Rinaldi S, Becker S, Lukanova A, Tjonneland A, Olsen A, Stegger J, Overvad K, Chabbert-Buffet N, Jimenez-Corona A, Clavel-Chapelon F, Rohrmann S, Teucher B, Boeing H, Schutze M, Trichopoulou A, Benetou V, Lagiou P, Palli D, Berrino F, Panico S, Tumino R, Sacerdote C, Redondo ML, Travier N, Sanchez MJ, Altzibar JM, Chirlaque MD, Ardanaz E, Bueno-de-Mesquita HB, van Duijnhoven FJ, Onland-Moret NC, Peeters PH, Hallmans G, Lundin E, Khaw KT, Wareham N, Allen N, Key TJ, Slimani N, Hainaut P, Romaguera D, Norat T, Riboli E, Kaaks R. Obesity, inflammatory markers, and endometrial cancer risk: a prospective case-control study. Endocr Relat Cancer. 2010; 17:1007-1019. [PubMed: 20843938]

5. Wang T, Rohan TE, Gunter MJ, Xue X, Wactawski-Wende J, Rajpathak SN, Cushman M, Strickler HD, Kaplan RC, Wassertheil-Smoller S, Scherer PE, Ho GY. A prospective study of inflammation markers and endometrial cancer risk in postmenopausal hormone nonusers. Cancer Epidemiol Biomarkers Prev. 2011; 20:971-977. [PubMed: 21415362]

6. Kilic G, Gurates B, Garon J, Kang H, Arun B, Lampley CE, Kurzel R, Ashfaq R. Expression of cyclooxygenase-2 in endometrial adenocarcinoma. Eur J Gynaecol Oncol. 2005; 26:271-274. [PubMed: 15991524]

7. Keser SH, Gul AE, Barisik NO, Cakir C, Sensu S, Kandemir NO, Karadayi N. The relationship of COX-2 expression with estrogen receptor, progesterone receptor and prognostic parameters in endometrial carcinomas. J Obstet Gynaecol Res. 2010; 36:560-566. [PubMed: 20598038]

8. Fowler JM, Ramirez N, Cohn DE, Kelbick N, Pavelka J, Ben-Shachar I, Morrison C. Correlation of cyclooxygenase-2 (COX-2) and aromatase expression in human endometrial cancer: tissue microarray analysis. Am J Obstet Gynecol. 2005; 192:1262-1271. discussion 1271-3. [PubMed: 15846217]

9. Ebert AD, Bartley J, David M. Aromatase inhibitors and cyclooxygenase-2 (COX-2) inhibitors in endometriosis: new questions--old answers? Eur J Obstet Gynecol Reprod Biol. 2005; 122:144150. [PubMed: 16157442]

10. Gates MA, Tworoger SS, Eliassen AH, Missmer SA, Hankinson SE. Analgesic use and sex steroid hormone concentrations in postmenopausal women. Cancer Epidemiol Biomarkers Prev. 2010; 19:1033-1041. [PubMed: 20332258]

11. Allen NE, Key TJ, Dossus L, Rinaldi S, Cust A, Lukanova A, Peeters PH, Onland-Moret NC, Lahmann PH, Berrino F, Panico S, Larranaga N, Pera G, Tormo MJ, Sanchez MJ, Ramon Quiros J, Ardanaz E, Tjonneland A, Olsen A, Chang-Claude J, Linseisen J, Schulz M, Boeing H, Lundin E, Palli D, Overvad K, Clavel-Chapelon F, Boutron-Ruault MC, Bingham S, Khaw KT, Bueno-deMesquita HB, Trichopoulou A, Trichopoulos D, Naska A, Tumino R, Riboli E, Kaaks R. Endogenous sex hormones and endometrial cancer risk in women in the European Prospective Investigation into Cancer and Nutrition (EPIC). Endocr Relat Cancer. 2008; 15:485-497. [PubMed: 18509001] 
12. Henderson BE, Ross RK, Pike MC, Casagrande JT. Endogenous hormones as a major factor in human cancer. Cancer Res. 1982; 42:3232-3239. [PubMed: 7046921]

13. Moysich KB, Baker JA, Rodabaugh KJ, Villella JA. Regular analgesic use and risk of endometrial cancer. Cancer Epidemiol Biomarkers Prev. 2005; 14:2923-2928. [PubMed: 16365011]

14. Fortuny J, Sima C, Bayuga S, Wilcox H, Pulick K, Faulkner S, Zauber AG, Olson SH. Risk of endometrial cancer in relation to medical conditions and medication use. Cancer Epidemiol Biomarkers Prev. 2009; 18:1448-1456. [PubMed: 19383893]

15. Viswanathan AN, Feskanich D, Schernhammer ES, Hankinson SE. Aspirin, NSAID, and acetaminophen use and the risk of endometrial cancer. Cancer Res. 2008; 68:2507-2513. [PubMed: 18381460]

16. Neill AS, Nagle CM, Protani MM, Obermair A, Spurdle AB, Webb PM. Aspirin, nonsteroidal antiinflammatory drugs, paracetamol and risk of endometrial cancer: A case-control study, systematic review and meta-analysis. Int J Cancer. 2012

17. Bodelon C, Doherty JA, Chen C, Rossing MA, Weiss NS. Use of nonsteroidal antiinflammatory drugs and risk of endometrial cancer. Am J Epidemiol. 2009; 170:1512-1517. [PubMed: 19897512]

18. Bosetti C, Bravi F, Talamini R, Montella M, Negri E, La Vecchia C. Aspirin and risk of endometrial cancer: a case-control study from Italy. Eur J Cancer Prev. 2010; 19:401-403. [PubMed: 20698055]

19. Danforth KN, Gierach GL, Brinton LA, Hollenbeck AR, Katki HA, Leitzmann MF, Schatzkin A, Lacey JV Jr. Nonsteroidal anti-inflammatory drug use and endometrial cancer risk in the NIHAARP Diet and Health Study. Cancer Prev Res (Phila). 2009; 2:466-472. [PubMed: 19401534]

20. Prizment AE, Folsom AR, Anderson KE. Nonsteroidal anti-inflammatory drugs and risk for ovarian and endometrial cancers in the Iowa Women's Health Study. Cancer Epidemiol Biomarkers Prev. 2010; 19:435-442. [PubMed: 20142241]

21. Setiawan VW, Matsuno RK, Lurie G, Wilkens LR, Carney ME, Henderson BE, Kolonel LN, Goodman MT. Use of Nonsteroidal Anti-inflammatory Drugs and Risk of Ovarian and Endometrial Cancer: The Multiethnic Cohort. Cancer Epidemiol Biomarkers Prev. 2012

22. Phipps AI, Anderson GL, Cochrane BB, Li CI, Wactawski-Wende J, Ho GY, O'Sullivan MJ, Newcomb PA. Migraine History, Nonsteroidal Anti-inflammatory Drug Use, and Risk of Postmenopausal Endometrial Cancer. Horm Cancer. 2012

23. Cook NR, Lee IM, Gaziano JM, Gordon D, Ridker PM, Manson JE, Hennekens CH, Buring JE. Low-dose aspirin in the primary prevention of cancer: the Women's Health Study: a randomized controlled trial. JAMA. 2005; 294:47-55. [PubMed: 15998890]

24. Rothwell PM, Price JF, Fowkes FG, Zanchetti A, Roncaglioni MC, Tognoni G, Lee R, Belch JF, Wilson M, Mehta Z, Meade TW. Short-term effects of daily aspirin on cancer incidence, mortality, and non-vascular death: analysis of the time course of risks and benefits in 51 randomised controlled trials. Lancet. 2012; 379:1602-1612. [PubMed: 22440946]

25. Bianchi M. Are all NSAIDs other than 'coxibs' really equal? Trends Pharmacol Sci. 2004; 25:6-7. [PubMed: 14723972]

26. White E, Patterson RE, Kristal AR, Thornquist M, King I, Shattuck AL, Evans I, Satia-Abouta J, Littman AJ, Potter JD. VITamins And Lifestyle cohort study: study design and characteristics of supplement users. Am J Epidemiol. 2004; 159:83-93. [PubMed: 14693663]

27. Grosser, T.; Smyth, E.; FitzGerald, G. Anti-inflammatory, antipyretic, and analgesic agents; Pharmacotherapy of Gout. In: Brunton, L., editor. Goodman and Gilman's The Pharmacological Basis of Therapeutics, 12th edition. 12th edition ed.. New York: McGraw Hill; 2011. p. 960-1004.

28. Field RW, Smith BJ, Platz CE, Robinson RA, Neuberger JS, Brus CP, Lynch CF. Lung cancer histologic type in the surveillance, epidemiology, and end results registry versus independent review. J Natl Cancer Inst. 2004; 96:1105-1107. [PubMed: 15265973]

29. Imhof A, Froehlich M, Brenner H, Boeing H, Pepys MB, Koenig W. Effect of alcohol consumption on systemic markers of inflammation. Lancet. 2001; 357:763-767. [PubMed: $11253971]$

30. Pradhan AD, Manson JE, Rossouw JE, Siscovick DS, Mouton CP, Rifai N, Wallace RB, Jackson RD, Pettinger MB, Ridker PM. Inflammatory biomarkers, hormone replacement therapy, and 
incident coronary heart disease: prospective analysis from the Women's Health Initiative observational study. JAMA. 2002; 288:980-987. [PubMed: 12190368]

31. Pierce BL, Neuhouser ML, Wener MH, Bernstein L, Baumgartner RN, Ballard-Barbash R, Gilliland FD, Baumgartner KB, Sorensen B, McTiernan A, Ulrich CM. Correlates of circulating $\mathrm{C}$-reactive protein and serum amyloid A concentrations in breast cancer survivors. Breast Cancer Res Treat. 2009; 114:155-167. [PubMed: 18401703]

32. Steed HL, Chu QS. Aromatase inhibition: a potential target for the management of recurrent or metastatic endometrial cancer by letrozole: more questions than answers? Expert Opin Investig Drugs. 2011; 20:681-690.

33. Brasky TM, Potter JD, Kristal AR, Patterson RE, Peters U, Asgari MM, Thornquist MD, White E. Non-steroidal anti-inflammatory drugs and cancer incidence by sex in the VITamins And Lifestyle (VITAL) cohort. Cancer Causes Control. 2012; 23:431-444. [PubMed: 22212612]

34. Brueggemeier RW, Diaz-Cruz ES, Li P-K, Sugimoto Y, Lin YC, Shapiro CL. Translational studies on aromatase, cyclooxygenases, and enzyme inhibitors in breast cancer. Journal of Steroid Biochemistry \& Molecular Biology. 2005; 95:129-136. [PubMed: 15964185]

35. Daikoku T, Hirota Y, Tranguch S, Joshi AR, DeMayo FJ, Lydon JP, Ellenson LH, Dey SK. Conditional loss of uterine Pten unfailingly and rapidly induces endometrial cancer in mice. Cancer Res. 2008; 68:5619-5627. [PubMed: 18632614]

36. Burke, A.; Smyth, E. Analgesic-antipyretic agents; pharmacotherapy of Gout. In: Brunton, LL.; Lazlo, JS.; Parker, KL., editors. Goodman \& Gilman's the pharmacological basis of therapeutics. 11th ed.. New York: McGraw-Hill; 2006. p. 671-716.

37. Gallagher CJ, Balliet RM, Sun D, Chen G, Lazarus P. Sex differences in UDPglucuronosyltransferase 2B17 expression and activity. Drug Metab Dispos. 2010; 38:2204-2209. [PubMed: 20810538]

38. Gallagher CJ, Muscat JE, Hicks AN, Zheng Y, Dyer AM, Chase GA, Richie J, Lazarus P. The UDP-glucuronosyltransferase 2B17 gene deletion polymorphism: sex-specific association with urinary 4-(methylnitrosamino)-1-(3-pyridyl)-1-butanol glucuronidation phenotype and risk for lung cancer. Cancer Epidemiol Biomarkers Prev. 2007; 16:823-828. [PubMed: 17416778]

39. Mollerup S, Berge G, Baera R, Skaug V, Hewer A, Phillips DH, Stangeland L, Haugen A. Sex differences in risk of lung cancer: Expression of genes in the PAH bioactivation pathway in relation to smoking and bulky DNA adducts. Int J Cancer. 2006; 119:741-744. [PubMed: 16557573]

40. Cole BF, Logan RF, Halabi S, Benamouzig R, Sandler RS, Grainge MJ, Chaussade S, Baron JA. Aspirin for the chemoprevention of colorectal adenomas: meta-analysis of the randomized trials. $\mathrm{J}$ Natl Cancer Inst. 2009; 101:256-266. [PubMed: 19211452]

41. Rothwell PM, Wilson M, Elwin CE, Norrving B, Algra A, Warlow CP, Meade TW. Long-term effect of aspirin on colorectal cancer incidence and mortality: 20-year follow-up of five randomised trials. Lancet. 2010; 376:1741-1750. [PubMed: 20970847]

42. Rothwell PM, Fowkes FG, Belch JF, Ogawa H, Warlow CP, Meade TW. Effect of daily aspirin on long-term risk of death due to cancer: analysis of individual patient data from randomised trials. Lancet. 2011; 377:31-41. [PubMed: 21144578]

43. Takkouche BR-MC, Etminan M. Breast cancer and use of nonsteroidal anti-inflammatory drugs: a meta-analysis. Journal of the National Cancer Institute. 2008; 100:1420-1423. [PubMed: 18840814] 


\section{Research Highlights}

- Existing studies of NSAIDs and endometrial cancer risk are inconsistent

- In this cohort study, aspirin linearly reduced endometrial cancer risk

- Individual non-aspirin NSAIDs were not associated with risk 
Table 1

Association between baseline characteristics of VITAL study participants and endometrial cancer, $n=22,268$.

\begin{tabular}{|c|c|c|c|}
\hline \multirow[b]{2}{*}{ Characteristic } & \multicolumn{2}{|c|}{ Endometrial Cancer } & \multirow[b]{2}{*}{$\begin{array}{l}\text { Age-adjusted } \\
\text { HR (95\% CI })\end{array}$} \\
\hline & $\begin{array}{c}\text { Case, } n=262 \\
\text { n }(\%)\end{array}$ & $\begin{array}{c}\text { Non-case, } n=22,006 \\
n(\%)\end{array}$ & \\
\hline \multicolumn{4}{|l|}{ Age, years } \\
\hline$<55$ & $58(22.14)$ & 6,399 (29.08) & \\
\hline $55-59$ & $61(23.28)$ & $5,409(24.58)$ & \\
\hline $60-65$ & 47 (17.94) & $3,635(16.52)$ & \\
\hline $65-69$ & $46(17.56)$ & $2,956(13.43)$ & \\
\hline$\geq 70$ & $50(19.08)$ & $3,607(16.39)$ & \\
\hline \multicolumn{4}{|l|}{ Race } \\
\hline White & $248(95.75)$ & $20,047(92.89)$ & 1.00 (reference) \\
\hline Black & $4(1.54)$ & $239(1.11)$ & $1.38(0.51-3.70)$ \\
\hline Other race & $7(2.70)$ & $1,295(6.00)$ & $0.44(0.21-0.94)$ \\
\hline \multicolumn{4}{|l|}{ Education } \\
\hline$\leq$ High school graduate & $45(17.44)$ & $4,504(20.88)$ & 1.00 (reference) \\
\hline Some college & $113(43.80)$ & $8,364(38.78)$ & $1.44(1.02-2.04)$ \\
\hline$\geq$ College graduate & $100(38.76)$ & $8,700(40.34)$ & $1.27(0.88-1.81)$ \\
\hline \multicolumn{4}{|l|}{ Body mass index, $\mathrm{kg} / \mathrm{m}^{2}$} \\
\hline$<25.0$ & $69(28.28)$ & $9,063(43.95)$ & 1.00 (reference) \\
\hline $25.0-29.9$ & $73(29.92)$ & $6,695(32.47)$ & $1.41(1.02-1.96)$ \\
\hline $30.0-34.9$ & 48 (19.67) & 2,939 (14.25) & $2.17(1.50-3.13)$ \\
\hline 235.0 & $54(22.13)$ & $1,923(9.33)$ & $3.91(2.73-5.59)$ \\
\hline$P$ trend & & & $<0.0001$ \\
\hline \multicolumn{4}{|l|}{ Smoking status } \\
\hline Never & $175(67.05)$ & $12,396(56.53)$ & 1.00 (reference) \\
\hline Former ( $\geq 10 y$ since quitting) & $65(4.62)$ & $6,541(29.89)$ & $0.71(0.39-1.27)$ \\
\hline Recent $(<10 y$ since quitting) & $12(4.62)$ & $1,226(5.60)$ & $0.70(0.52-0.93)$ \\
\hline Current & $8(3.08)$ & $1,723(7.87)$ & $0.35(0.17-0.71)$ \\
\hline \multicolumn{4}{|l|}{ Smoking, pack-years } \\
\hline Non-smoker & $175(67.05)$ & $12,396(56.68)$ & 1.00 (reference) \\
\hline$<7.5$ & $33(12.64)$ & $3,606(16.49)$ & $0.65(0.44-0.94)$ \\
\hline $7.5-25.0$ & $27(10.34)$ & $3,004(13.74)$ & $0.64(0.43-0.96)$ \\
\hline$\geq 25.0$ & $26(9.96)$ & $2,865(13.10)$ & $0.66(0.43-0.99)$ \\
\hline$P$ trend & & & $<0.01$ \\
\hline \multicolumn{4}{|l|}{ Alcohol, drinks/day } \\
\hline Non-drinker & $95(37.25)$ & $7,180(33.59)$ & 1.00 (reference) \\
\hline$<1.0$ & $127(49.80)$ & $10,650(49.83)$ & $0.91(0.70-1.19)$ \\
\hline $1-1.9$ & $21(8.24)$ & $2,109(9.87)$ & $0.75(0.47-1.21)$ \\
\hline$\geq 2.0$ & $12(4.71)$ & $1,435(6.71)$ & $0.63(0.35-1.16)$ \\
\hline$P$ trend & & & 0.08 \\
\hline
\end{tabular}




\begin{tabular}{|c|c|c|c|}
\hline \multirow[b]{2}{*}{ Characteristic } & \multicolumn{2}{|c|}{ Endometrial Cancer } & \multirow[b]{2}{*}{$\begin{array}{l}\text { Age-adjusted } \\
\text { HR }(95 \% \text { CI })\end{array}$} \\
\hline & $\begin{array}{l}\text { Case, } n=262 \\
\text { n }(\%)\end{array}$ & $\begin{array}{c}\text { Non-case, } n=22,006 \\
n(\%)\end{array}$ & \\
\hline \multicolumn{4}{|c|}{ Physical activity, MET-hours/wk } \\
\hline Inactive & $39(15.12)$ & $3,079(14.17)$ & 1.00 (reference) \\
\hline$<3.7$ & $83(32.17)$ & $6,263(28.82)$ & $1.03(0.71-1.51)$ \\
\hline $3.7-11.4$ & $75(29.07)$ & $6,142(28.27)$ & $0.94(0.64-1.39)$ \\
\hline$\geq 11.4$ & $61(23.64)$ & $6,245(28.74)$ & $0.75(0.50-1.13)$ \\
\hline$P$ trend & & & 0.08 \\
\hline \multicolumn{4}{|l|}{ Reproductive Health } \\
\hline \multicolumn{4}{|c|}{ Age at menarche, years } \\
\hline$\leq 1$ & $56(21.46)$ & $3,699(16.89)$ & 1.00 (reference) \\
\hline 12 & $81(31.03)$ & $6,507(29.70)$ & $0.83(0.59-1.16)$ \\
\hline 13 & $73(27.97)$ & $6,648(30.35)$ & $0.72(0.51-1.02)$ \\
\hline$\geq 14$ & $51(19.54)$ & $5,053(23.07)$ & $0.65(0.45-0.96)$ \\
\hline$P$ trend & & & 0.02 \\
\hline \multicolumn{4}{|c|}{ Age at menopause, years } \\
\hline$\$ 44$ & $18(7.23)$ & 2,647 (12.29) & 1.00 (reference) \\
\hline $45-49$ & $58(23.29)$ & $5,646(26.22)$ & $1.55(0.91-2.63)$ \\
\hline 250 & $144(57.83)$ & $10,848(50.37)$ & $1.89(1.16-3.09)$ \\
\hline Premenopausal & $11(4.42)$ & $1,333(6.19)$ & $1.61(0.73-3.52)$ \\
\hline Perimenopausal & $18(7.23)$ & $1,062(4.93)$ & $3.29(1.66-6.54)$ \\
\hline \multicolumn{4}{|l|}{ Parity } \\
\hline Nulliparous & $49(19.68)$ & $3,106(15.23)$ & 1.00 (reference) \\
\hline $1-2$ & $109(43.78)$ & $9,267(45.43)$ & $0.72(0.51-1.00)$ \\
\hline $3-4$ & $78(31.33)$ & $6,527(32.00)$ & $0.65(0.45-0.94)$ \\
\hline 25 & $13(5.22)$ & $1,499(7.35)$ & $0.45(0.24-0.84)$ \\
\hline$P$ trend & & & $<0.01$ \\
\hline \multicolumn{4}{|c|}{ Combined hormone therapy } \\
\hline Never & $146(67.59)$ & $10,596(57.39)$ & 1.00 (reference) \\
\hline Former & $28(12.96)$ & $1,878(10.17)$ & $0.99(0.66-1.48)$ \\
\hline Current & $42(19.44)$ & $5,988(32.43)$ & $0.50(0.35-0.70)$ \\
\hline \multicolumn{4}{|c|}{ Years of combined hormone therapy } \\
\hline Never & $151(60.40)$ & $10,725(51.56)$ & 1.00 (reference) \\
\hline $1-4$ & $39(15.60)$ & $3,492(16.79)$ & $0.83(0.58-1.18)$ \\
\hline $5-9$ & $28(11.20)$ & $3,114(14.97)$ & $0.61(0.40-0.91)$ \\
\hline$\geq 10$ & $32(12.80)$ & $3,471(16.69)$ & $0.56(0.38-0.83)$ \\
\hline$P$ trend & & & $<0.001$ \\
\hline \multicolumn{4}{|c|}{ Estrogen-only hormone therapy } \\
\hline Never & $193(89.35)$ & $16,543(89.61)$ & 1.00 (reference) \\
\hline Former & $17(7.87)$ & $1,319(7.14)$ & $1.01(0.61-1.66)$ \\
\hline Current & $6(2.78)$ & $600(3.25)$ & $0.84(0.37-1.89)$ \\
\hline
\end{tabular}

Years of estrogen-only hormone therapy 


\begin{tabular}{|c|c|c|c|}
\hline \multirow[b]{2}{*}{ Characteristic } & \multicolumn{2}{|c|}{ Endometrial Cancer } & \multirow[b]{2}{*}{$\begin{array}{l}\text { Age-adjusted } \\
\text { HR }(95 \% \text { CI })\end{array}$} \\
\hline & $\begin{array}{c}\text { Case, } n=262 \\
\text { n }(\%)\end{array}$ & $\begin{array}{c}\text { Non-case, } n=22,006 \\
n(\%)\end{array}$ & \\
\hline Never & $204(89.08)$ & $17,271(89.47)$ & 1.00 (reference) \\
\hline $1-4$ & $5(2.18)$ & $615(3.19)$ & $0.69(0.28-1.66)$ \\
\hline $5-9$ & $12(5.24)$ & $918(4.76)$ & $1.02(0.57-1.83)$ \\
\hline$\geq 10$ & $8(3.49)$ & $499(2.59)$ & $1.21(0.59-2.45)$ \\
\hline$P$ trend & & & 0.78 \\
\hline \multicolumn{4}{|c|}{ Years of oral contraceptive use } \\
\hline Never & $103(39.62)$ & $5,739(26.36)$ & 1.00 (reference) \\
\hline$\leq 4$ & $93(35.77)$ & $8,229(37.79)$ & $0.62(0.46-0.85)$ \\
\hline $5-9$ & $39(15.00)$ & $4,007(18.40)$ & $0.54(0.36-0.80)$ \\
\hline$\geq 10$ & $25(9.62)$ & 3,798 (17.44) & $0.36(0.23-0.57)$ \\
\hline$P$ trend & & & $<0.0001$ \\
\hline \multicolumn{4}{|l|}{ Oophoerectomy } \\
\hline No & $249(95.04)$ & $21,144(96.08)$ & 1.00 (reference) \\
\hline Yes & $13(4.96)$ & $862(3.92)$ & $1.28(0.73-2.23)$ \\
\hline \multicolumn{4}{|c|}{ Family and Medical History } \\
\hline \multicolumn{4}{|c|}{ Family history of uterine cancer } \\
\hline No & $234(91.05)$ & $20,702(94.88)$ & 1.00 (reference) \\
\hline Yes & $23(8.95)$ & $1,116(5.12)$ & $1.81(1.18-2.78)$ \\
\hline \multicolumn{4}{|c|}{ Family history of ovarian cancer } \\
\hline No & $243(94.19)$ & $21,089(96.65)$ & 1.00 (reference) \\
\hline Yes & $15(5.81)$ & $731(3.35)$ & $1.78(1.06-3.00)$ \\
\hline \multicolumn{4}{|c|}{ History of diabetes } \\
\hline No & $248(94.66)$ & $20,883(94.90)$ & 1.00 (reference) \\
\hline Yes & $14(5.34)$ & $1,123(5.10)$ & $1.06(0.62-1.81)$ \\
\hline
\end{tabular}

Abbreviations: HR, hazard ratio; 95\% CI, 95\% confidence interval 
Table 2

Association between non-steroidal anti-inflammatory drug use and endometrial cancer risk in the VITAL study, $n=22,268$.

\begin{tabular}{|c|c|c|c|c|}
\hline NSAID & Non-use & Low $(<4 d / w k$ or $<4 y)$ & High ( $\geq \mathbf{4} d /$ wk and $\geq 4 y$ ) & $P$ trend \\
\hline \multicolumn{5}{|l|}{ Total NSAIDs } \\
\hline Cases/Non-cases & $110 / 8,844$ & $81 / 6,845$ & $47 / 4,055$ & \\
\hline Age \& NSAID-adjusted HR (95\% CI) & 1.00 (reference) & $0.94(0.71-1.25)$ & $0.89(0.63-1.25)$ & 0.48 \\
\hline Multivariable-adjusted HR $(95 \% \mathrm{CI})^{a}$ & 1.00 (reference) & $0.95(0.69-1.29)$ & $0.83(0.56-1.22)$ & 0.35 \\
\hline \multicolumn{5}{|l|}{ Aspirin } \\
\hline Cases/Non-cases & $166 / 12,936$ & $50 / 4,682$ & $32 / 2,936$ & \\
\hline Age \& NSAID-adjusted HR (95\% CI) & 1.00 (reference) & $0.76(0.54-1.05)$ & $0.74(0.50-1.10)$ & 0.06 \\
\hline Multivariable-adjusted HR $(95 \% \mathrm{CI})^{a}$ & 1.00 (reference) & $0.77(0.54-1.09)$ & $0.64(0.41-1.01)$ & 0.03 \\
\hline \multicolumn{5}{|l|}{ Low-dose aspirin } \\
\hline Cases/Non-cases & $195 / 15,842$ & $35 / 3,298$ & $24 / 1,820$ & \\
\hline Age \& NSAID-adjusted HR (95\% CI) & 1.00 (reference) & $0.77(0.52-1.13)$ & $1.00(0.65-1.56)$ & 0.56 \\
\hline Multivariable-adjusted HR $(95 \% \mathrm{CI})^{a}$ & 1.00 (reference) & $0.81(0.54-1.21)$ & $1.00(0.62-1.62)$ & 0.65 \\
\hline \multicolumn{5}{|l|}{ Regular-strength aspirin } \\
\hline Cases/Non-cases & $214 / 17,423$ & $25 / 2,476$ & $14 / 1,521$ & \\
\hline Age \& NSAID-adjusted HR (95\% CI) & 1.00 (reference) & $0.84(0.55-1.29)$ & $0.66(0.37-1.19)$ & 0.12 \\
\hline Multivariable-adjusted HR $(95 \% \mathrm{CI})^{a}$ & 1.00 (reference) & $0.85(0.55-1.32)$ & $0.53(0.27-1.04)$ & 0.06 \\
\hline \multicolumn{5}{|l|}{ Non-aspirin } \\
\hline Cases/Non-cases & $164 / 14,002$ & $65 / 5,387$ & $21 / 1,535$ & \\
\hline Age \& NSAID-adjusted HR (95\% CI) & 1.00 (reference) & $1.11(0.83-1.50)$ & $1.27(0.80-2.01)$ & 0.25 \\
\hline Multivariable-adjusted HR $(95 \% \mathrm{CI})^{a}$ & 1.00 (reference) & $1.16(0.84-1.60)$ & $1.15(0.68-1.95)$ & 0.40 \\
\hline \multicolumn{5}{|l|}{ Ibuprofen } \\
\hline Cases/Non-cases & $178 / 15,541$ & $55 / 4,447$ & $18 / 1,232$ & \\
\hline Age \& NSAID-adjusted HR (95\% CI) & 1.00 (reference) & $1.27(0.82-1.73)$ & $1.50(0.92-1.73)$ & 0.04 \\
\hline Multivariable-adjusted HR $(95 \% \mathrm{CI})^{a}$ & 1.00 (reference) & $1.31(0.94-1.83)$ & $1.29(0.73-2.28)$ & 0.12 \\
\hline \multicolumn{5}{|l|}{ Naproxen } \\
\hline Cases/Non-cases & $243 / 19,685$ & $13 / 1,695$ & $5 / 329$ & \\
\hline Age \& NSAID-adjusted HR (95\% CI) & 1.00 (reference) & $0.54(0.29-1.01)$ & $1.26(0.51-3.08)$ & 0.30 \\
\hline Multivariable-adjusted HR $(95 \% \mathrm{CI})^{a}$ & 1.00 (reference) & $0.54(0.28-1.04)$ & $1.08(0.39-2.95)$ & 0.23 \\
\hline
\end{tabular}

Abbreviations: NSAID, non-steroidal anti-inflammatory drug; HR, hazard ratio; 95\% CI, 95\% confidence interval

${ }^{a}$ Adjusted for age (time variable), race, education, body mass index, pack-years of smoking, alcohol consumption, physical activity, age at menarche, age at menopause, parity, combined hormone therapy, estrogen-only hormone therapy, years of oral contraceptive use, oophoerectomy, family history of uterine cancer, family history of ovarian cancer, history of diabetes, history of coronary artery disease, history of stroke, history of osteoarthritis/chronic joint pain, history of rheumatoid arthritis, history of migraine/chronic headaches, history of ulcers, and other NSAIDs. 
Table 3

Association between aspirin use and endometrial cancer risk, stratified by smoking status, body mass index, and combined hormone replacement therapy.

\begin{tabular}{|c|c|c|}
\hline \multirow[b]{2}{*}{ NSAID } & \multicolumn{2}{|c|}{ Multivariable-adjusted HR $(95 \% \mathrm{CI})^{a}$} \\
\hline & Non-user & Ever Use ( $\geq 1 d / w k$ and $\geq 1 y)$ \\
\hline \multicolumn{3}{|l|}{ Any Aspirin } \\
\hline Never smoker & 1.00 (reference) & $0.55(0.37-0.82)$ \\
\hline \multirow[t]{2}{*}{ Ever smoker } & 1.00 (reference) & $1.25(0.77-2.04)$ \\
\hline & & $P$ interaction $=0.04$ \\
\hline \multicolumn{3}{|l|}{ Low-dose aspirin } \\
\hline Never smoker & 1.00 (reference) & $0.73(0.48-1.13)$ \\
\hline \multirow[t]{2}{*}{ Ever smoker } & 1.00 (reference) & $1.30(0.77-2.20)$ \\
\hline & & $P$ interaction $=0.18$ \\
\hline \multicolumn{3}{|c|}{ Regular-strength aspirin } \\
\hline Never smoker & 1.00 (reference) & $0.64(0.40-1.05)$ \\
\hline \multirow[t]{2}{*}{ Ever smoker } & 1.00 (reference) & $0.92(0.50-1.71)$ \\
\hline & & $P$ interaction $=0.51$ \\
\hline \multicolumn{3}{|l|}{ Any Aspirin $b$} \\
\hline Never/former HRT & 1.00 (reference) & $0.98(0.66-1.45)$ \\
\hline \multirow[t]{2}{*}{ Current HRT user } & 1.00 (reference) & $0.49(0.22-1.10)$ \\
\hline & & $P$ interaction $=0.10$ \\
\hline \multicolumn{3}{|l|}{ Low-dose aspirin $b$} \\
\hline Never/former HRT & 1.00 (reference) & $1.25(0.83-1.88)$ \\
\hline \multirow[t]{2}{*}{ Current HRT user } & 1.00 (reference) & $0.57(0.23-1.43)$ \\
\hline & & $P$ interaction $=0.09$ \\
\hline \multicolumn{3}{|c|}{ Regular-strength aspirin $b$} \\
\hline Never/former HRT & 1.00 (reference) & $0.84(0.52-1.37)$ \\
\hline \multirow[t]{2}{*}{ Current HRT user } & 1.00 (reference) & $0.52(0.18-1.53)$ \\
\hline & & $P$ interaction $=0.36$ \\
\hline \multicolumn{3}{|l|}{ Any Aspirin } \\
\hline BMI $<30$ & 1.00 (reference) & $0.73(0.48-1.10)$ \\
\hline \multirow[t]{2}{*}{ BMI $\geq 30$} & 1.00 (reference) & $0.67(0.41-1.09)$ \\
\hline & & $P$ interaction $=0.40$ \\
\hline \multicolumn{3}{|l|}{ Low-dose aspirin } \\
\hline BMI <30 & 1.00 (reference) & $0.90(0.57-1.40)$ \\
\hline \multirow[t]{2}{*}{ BMI $\geq 30$} & 1.00 (reference) & $0.92(0.54-1.58)$ \\
\hline & & $P$ interaction $=0.71$ \\
\hline \multicolumn{3}{|c|}{ Regular-strength aspirin } \\
\hline BMI $<30$ & 1.00 (reference) & $0.74(0.44-1.24)$ \\
\hline \multirow[t]{2}{*}{ BMI $\geq 30$} & 1.00 (reference) & $0.60(0.31-1.15)$ \\
\hline & & $P$ interaction $=0.42$ \\
\hline
\end{tabular}

Gynecol Oncol. Author manuscript; available in PMC 2014 January 01. 
Abbreviations: HR, hazard ratio; 95\% CI, 95\% confidence interval; BMI, body mass index; HRT, combined hormone replacement therapy

${ }^{a}$ Adjusted for age (time variable), race, education, body mass index, pack-years of smoking, alcohol consumption, physical activity, age at menarche, age at menopause, parity, combined hormone therapy, estrogen-only hormone therapy, years of oral contraceptive use, oophoerectomy, family history of uterine cancer, family history of ovarian cancer, history of diabetes, history of coronary artery disease, history of stroke, history of osteoarthritis/chronic joint pain, history of rheumatoid arthritis, history of migraine/chronic headaches, history of ulcers, and other NSAIDs

$b_{\text {Among post-menopausal women only }}$ 